\author{
Doga-Mirzac M. \\ PhD Habilitat of Economic Sciences, Associate Professor \\ Department Finance and Banks \\ State University of Moldova \\ str. Alexei Mateevici 60, Chisinau, Moldova, MD-2009 \\ E-mail: mariana.mirzac@yahoo.com \\ ORCID: 0000-0003-0217-7398
}

\title{
INDICATORS FOR THE EVALUATION AND MONITORING ACTIVITY OF THE UNIVERSITY INCUBATOR
}

The purpose of the article is to propose the indicators for the evaluation and monitoring activity, the developing structure and functioning of business incubators located in the academic environment which would allow the organization of internal and external processes for researchers and students. The success of a business incubator in the university environment represents primarily its value for the university and for the economic environment and the ability to react quickly to changing conditions inside and outside and developing the entrepreneurial ecosystem at national level. The degree of development of university incubators, the capacity and quality of their functioning depends not only on the intensity of the support of the environment in which they operate, but also on their efficiency through attractiveness, promoting viable businesses and at the same time being an alternative source of financing and propelling potential entrepreneurs.

Keywords: evaluation indicator, business incubator, business environment, young entrepreneurs, accelerator, small and medium enterprises.

This work is licensed under a Creative Commons Attribution 4.0 International License http://creativecommons.org/licenses/by/4.0/

Statement of the problem and its connection with important scientific and practical tasks. One of the most important directions of the state support is currently to strengthen and improve business relations with the research institutes. There are various forms of cooperation between the science and business: carrying out research commissioned by companies; researchers advise the entrepreneurs; companies buy a completed research project; researchers cooperate with businessmen within association; joint implementation of the project, etc. One of the most promising possibilities to strengthen the cooperation between the science and business is the activity of innovation incubators set up within research/university institutes $[1 ; 2 ; 3 ; 5$, p.94]

In turn, performance and success can be analyzed through two important categories: 1. objective of the business incubator as an economic mechanism within a local, regional, national policy, as well as 2 . effectiveness of individual/institutional entrepreneurship development programs.

Thus, to measuring of the performance of a classical business incubator (BI) includes the application of the following indicators:

- Efficiency of BI activities: number of companies assisted through different provided services; number of tenants of the BI and staff of each company; occupancy rate of the $\mathrm{BI}$; rate of companies leaving the $\mathrm{BI}$; assessment of management and services needed by each entrepreneur;

- Viability of BI: assessment of efficiency in terms of supporting organizations' quality; annual income and expenditure; year of financial accumulation; annual number of companies able to leave the BI and those going out of business;

- Economic and social impact: number of jobs created in the BI; added value created by the tenant companies; degree of using the university laboratories; impact on the region's economy, etc. [9, p.114]

To develop the system of indicators it is necessary to take into account not only the static activity, but also the dynamic changes in the efficiency of the business incubators activity located in the university environment.

The analysis of the latest publications on the problem. A starting point in researching the aspects aimed at evaluating and monitoring activity of business incubators located in university environment is based on the scientific work of the researchers dedicated to evaluation of business incubators. For a deeper knowledge of the objectives of the research, the following authors' visions were examined: Rogova E. [6], Galiyeva N [7]., Gabor V. [4], Timotin L. [5], Tormisheva T. [8], Veverița A., Znaceni A. [10]. The obtained results, whether positive or negative, lead to the fact, that the business incubator activity must be monitored and analysed, using methods or indicators that would allow us to direct them towards the development of both academic and economic environment; this environment is a component (link) of the economic-financial system, which drives the mechanism aimed to evaluate and monitor the results that will beneficially influence the economy and education.

Forming of the aims of the research. The purpose of the article is to propose the indicators for the 
evaluation and monitoring activity, the developing and functioning structure of business incubators located in the academic environment which would allow the organization of internal and external processes for researchers and students. This research is a component part of the research project "Multidimensional evaluation and development of the entrepreneurial ecosystem at national and regional level in order to boost the SME sector in the Republic of Moldova".

Giving an account of the main results and their substantiation.. When selecting the evaluation indicators the benefit to the local community should also be taken into account, as well as the efficiency of the financial or human resources used to achieve the proposed objectives. The indicators used in the evaluation and analysis of BI productivity and efficiency can be divided into two groups depending on the source of the statistical data:

- indicators as objective data source (statistical (official) data of the state organisations)

- indicators as subjective data source (data obtained from surveys, interviews, polls of the staff working with the university and the incubator located in the same environment or enterprises, both incubated and not)

In order to assess the efficiency of the activity and development of the UI (University incubator), we can also use the integral index method, which can be calculated as the geometric mean of the individual indicators change by status and development of enterprises within the BI, (used from the table) according to the following formula (1):

$$
l i=\sqrt[n]{i_{1} \times i_{2} \times \ldots i_{n}},
$$

where:

$I i$ - integral index of performance in evaluating and monitoring the Business Incubator within the university environment;

$i_{1}, i_{2}, \ldots, i_{n}-$ indicators characterizing the activity and development of the university incubator during the period under review $[1,2,5,6,7,10]$.

Applyicataion of the proposed method allows us to bring to a common denominator the indicators that are measured in different units and gives us the opportunity to analyze the individual indicators in dynamics.

The used method involves the calculation and highlighting of five indicators with a tactical objective embedded into the strategic objectives to establish and develop the small and medium-sized businesses within the UI, namely: the Integral Index of Establishment and Monitoring the Incubated Businesses (IIMIB); the Integral Index of Efficient Use of the Financial Resources (IEUFR); the Integral Index of Efficient Use of the $\mathrm{Hu}-$ man Resources (IEUHR); the Integral Index Characterising the University Environment (ICUE); the Integral Index of Efficient Use and Promotion of Innovations (IUPI).

The next stage, according to the similar principle, shows the structure of the consolidated integral indicator oriented to evaluate and monitor the Business Incubator within the university environment [2]:

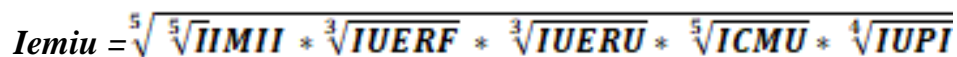

Highlighting the financial resources section, we mention that: the integral indicator of attraction and efficient use of financial resources (IUERF) can be applied individually, which will allow both incubated enterprises and the incubator to analyze the situation and to efficiently use the financial resources.

Finally we can present the formula of the Integral Indicator of Efficient Use of the Financial Resources by the enterprises which operate within the business incubators and the business incubator itself:

$$
I U E R F=\sqrt[3]{I_{1} \times I_{2} \times I_{3}}
$$

where:

$\boldsymbol{I}_{\boldsymbol{1}}$ - financial resources of the incubator/enterprise from the state budget sources,

$\boldsymbol{I}_{2}$ - financial funds of the incubator/enterprise from the local/university budget,

$\boldsymbol{I}_{\mathbf{3}}$ - financial resources of enterprises from the financial market.

Focusing on the indicator $\left(\mathbf{I}_{\mathbf{1}}\right)$ of the incubator's resources financed from the state budget, which is a component of the Integrated Indicator of the efficient use of financial resources for the registration of grants to establish the technological business incubator within the university environment, it is necessary to assess the financial sustainability by applying the following questions:
- Are the planned expenditures realistic? Is the planned duration of the financial plan realistic?

- Can the investor ensure a financial stability? (based on the evaluation of the balance sheet, profit and loss statement, annual reports, liquidity and financial capital)

- Assessment of the applicant's liquidity (liquidity ratio, liquidity assessment ratio)

- Have the relevant risks been assessed and identified? Does the investor have a detailed plan of the likely risks?

- Is long-term sustainability ensured? Are the planned costs to ensure sustainability adequately assessed and presented? [4, p.128].

In the framework of the South East Europe Transnational Cooperation Programme oriented towards the Development of Innovative Industrial Parks to strengthen innovations and entrepreneurship some performance indicators / financial indicators have been recommended by the Regional Development Company: Net present value (NPV), Internal rate of return, Payback period, Return on investment (ROI), Cost-benefit ratio, Equity ratio, Interest coverage ratio, Probability of profit [4, p.133]

Concurrently with the identification and formulation of indicators, sources of verification of the objectives (SVO) are also specified. The objectives sources 
of verification indicate where and in what form the information about the objectives' (general and specific) achievement and project results can be found. With this aid we will be able to identify whether or not the indicators can realistically be measured at a given level of time, cost and effort. The SVO must answer certain questions: 1. How and from where the information will be collected (e.g. progress and/or financial report, specific studies, surveys, official statistics, etc.); 2. Who should collect and provide the information (e.g. experts, project team, etc.); 3 . When/how often the information should be provided (e.g. monthly, annually, etc.).

Furthermore, all the above mentioned can be applied only if there is a manager and an active team within the UI, who through their skills and experience develop and drive the activity and they are the determining factor in attracting/retaining and promoting young people from the university environment.

\section{vestigations:}

Conclusions and prospects of the further in-

- It is obvious that in order to achieve successful results and to develop the activity of the Business Incubator within the university environment, it is necessary to monitor and evaluate each process according to the activity plan and the obtained results by involving both the management team and the University human resources and management.
- The obtained results, whether positive or negative, must be analyzed using such methods that would allow the university and economic environment to develop; this environment is a link of the economicfinancial system, which drives the mechanism aimed to evaluate and monitor the results that will beneficially influence the economy and entrepreneurial education.

- The performance and success of the university incubator can be analyzed by applying two important categories: indicators from objective data source (statistical data from the state organizations) and indicators from subjective data source (data obtained from inquiry, interview, survey):

- Application of the integral indicator oriented to evaluate and monitor the Business Incubator within the university environment can be used to assess and evaluate the effectiveness of the UI, directly oriented to support and develop the activity of enterprises and especially of the students and teaching staff who are involved in the university business environment.

- The assessment of the financial sustainability of the incubator and of the situation oriented towards the access and efficient use of the financial resources can be calculated using the Integral Index of the financial resources use by the enterprises operating within the business incubators and by the business incubator itself.

\section{References}

1. Doga-Mirzak, M., \& Naval, E. (2014). Theoretical and methodological approaches on the evaluation of business incubators. Journal of Financial and Monetary Economics, (1), 252-256.

2. Doga-Mirzak, M. (2015). Gestiunea sistemului de financiare a businessului mic shi mijlociu in contextual dezvolterii proceselor economice (dissertation... teza de doctor habilitat in shtiince economice). USM, Chishineu.

3. Gabor, V. \& Andras, G. sh.a. (2010). (Document de lucru 4). Manualul Parcurilor Industriale Inovative in regiunea SEE, "FIDIBE” (pp. 1-134). Compania de Dezvoltare Regionale "Kozep-Pannon“.

4. Timotin, L. (2017). Dezvoltarea activitecilor de antreprenoriat in Republica Moldova (dissertation... teze de doctor in shtiincțe economice), UTM, Chishineu.

5. Rogova, E. (2013). Effektivnost funktsionirovaniya biznes-inkubatorov kak elementa spin-off strategii universitetov. Innovatsionnaya ekonomika, (10 (180)), 58-63. Retrieved October 20, 2021, from https://cyberleninka.ru/article/n/effektivnost-funktsionirovaniya-biznes-inkubatorov-kak-elementa-spin-off-strategiiuniversitetov/viewer

6. Galieva, N. G., Devid, L. Fuski, \& Nikulshin, B. V. (2019). Pervonachalnye rezultaty issledovaniya v izmerenii effektivnosti deyatelnosti biznes-inkubatorov. International Journal of Open Information Technologies, 7(1). Retrieved October 20, 2021, from https://cyberleninka.ru/article/n/pervonachalnye-rezultaty-issledovaniya-v-izmereniieffektivnosti-deyatelnosti-biznes-inkubatorov/viewer

7. Tormisheva, T., Tekhnologiya «vyrashchivaniya» malykh innovatsionnykh kompaniy malogo biznesa. Nekommercheskoe Partnerstvo «Instituty razvitiya malogo i srednego biznesa». Retrieved October 20, 2021, from http://www.myshared.ru/slide/160454/

8. Dodu, A. (2009). Conceptul incubatorului de afaceri ca forme de promovare a IMM-urilor. Meridian Ingineresc, (3), 75-77. Retrieved October 20, 2021, from http://repository.utm.md/handle/5014/1440

9. Veverica, A., Znaceni, A. sh.a. (2015). Ghidul autoritecilor publice locale: elaborarea proiectelor, 1-131, Retrieved October 20, 2021, from https://www.calm.md/public/files/ghiduri/elaborare_proiect_ROM.pdf

10. Stratan, A., \& Doga-Mirzak, M. (2016). ASHM, INCE, Sistemul de financare a intreprinderilor mici shi mijlocii, 1-164. 


\author{
Дога-Мірзак М. \\ доктор економічних наук, доцент \\ кафедра фінансів та банківської справи \\ Державний університет Молдови \\ вул. Олексія Матеєвича 60, Кишинів,Молдова,MD-2009 \\ E-mail: mariana.mirzac@yahoo.com \\ ORCID: 0000-0003-0217-7398
}

\title{
ПОКАЗНИКИ ОЦІНКИ ТА МОНІТОРИНГУ ДІЯЛЬНОСТІ УНІВЕРСИТЕТСЬКОГО ІНКУБАТОРА
}

Мета статті полягала у розробці показників для здійснення оціночно-моніторингової діяльності та пропозицій щодо структури розвитку та функціонування бізнес-інкубаторів, розташованих в академічному середовищі, які б дозволили організувати внутрішні та зовнішні процеси науковців та студентів. Успіх бізнес-інкубатора в університетському середовищі представляє його цінність насамперед для університету та економічного середовища і водночас здатність швидко реагувати на мінливі умови всередині та зовні, тим самим стимулюючи та розвиваючи підприємницьку екосистему на національному рівні. Ступінь розвитку університетських інкубаторів, потужність та якість їхньої роботи залежать не тільки від інтенсивності підтримки університетського середовища в якому вони працюють, але й від їхньої ефективності за рахунок привабливості, просування життєздатного бізнесу і, водночас, $є$ альтернативним джерелом фінансування та стимулювання потенційних підприємців. У статті запропоновано дві групи показників оцінки продуктивності та ефективності бізнес-інкубаторів залежно від джерела статистичних даних: показники як об'єктивне джерело даних за офіційною статистикою та індикатори, отримані в результаті інтерв'ю, опитувань співробітників, що працюють з університетом та інкубатором, розташованими в одному середовищі або підприємствах, як інкубованих, так і неінкубованих. Для оцінки ефективності діяльності та розвитку Університетського інкубатора запропоновано використовувати метод інтегрального індексу, розрахованого як середнє геометричне зміни окремих показників за станом і розвитком підприємств у межах бізнес-інкубатора. Запропоновано використання п'яти показників із тактичною метою, закладеною у стратегічні цілі створення та розвитку малого та середнього бізнесу в рамках університетських інкубаторів, що охоплюють наступні Інтегральний індекси: створення та моніторингу інкубованих підприємств; ефрективного використання фрінансових ресурсів, ефрективного використання людських ресурсів; характеристики університетського середовища; ефективного використання та просування інновацій. Оцінку фінансової стійкості інкубатора та ситуації, орієнтованої на доступ та ефективного використання фрінансових ресурсів, запропоновано розрахувати за допомогою Інтегрального індексу використання фінансових ресурсів підприємствами, що працюють у бізнес-інкубаторах, та самим бізнес-інкубатором.

Ключові слова: показники оцінки діяльності бізнес-інкубатора, бізнес-інкубатор в університетському середовищі, бізнес-середовище, молоді підприємці, малі та середні підприємства.

\section{Лiтература}

1. Doga-Mirzak, M., \& Naval, E. (2014). Theoretical and methodological approaches on the evaluation of business incubators. Journal of Financial and Monetary Economics, (1), 252-256.

2. Doga-Mirzak, M. (2015). Gestiunea sistemului de financiare a businessului mic shi mijlociu in contextual dezvolterii proceselor economice (dissertation... teza de doctor habilitat in shtiince economice). USM, Chishineu.

3. Gabor, V. \& Andras, G. sh.a. (2010). (Document de lucru 4). Manualul Parcurilor Industriale Inovative in regiunea SEE, "FIDIBE” (pp. 1-134). Compania de Dezvoltare Regionale "Kozep-Pannon“.

4. Timotin, L. (2017). Dezvoltarea activitecilor de antreprenoriat in Republica Moldova (dissertation... teze de doctor in shtiincţe economice), UTM, Chishineu.

5. Rogova, E. (2013). Effektivnost funktsionirovaniya biznes-inkubatorov kak elementa spin-off strategii universitetov. Innovatsionnaya ekonomika, (10 (180)), 58-63. Retrieved October 20, 2021, from https://cyberleninka.ru/article/n/effektivnost-funktsionirovaniya-biznes-inkubatorov-kak-elementa-spin-off-strategiiuniversitetov/viewer

6. Galieva, N. G., Devid, L. Fuski, \& Nikulshin, B. V. (2019). Pervonachalnye rezultaty issledovaniya v izmerenii effektivnosti deyatelnosti biznes-inkubatorov. International Journal of Open Information Technologies, 7(1). Retrieved October 20, 2021, from https://cyberleninka.ru/article/n/pervonachalnye-rezultaty-issledovaniya-v-izmereniieffektivnosti-deyatelnosti-biznes-inkubatorov/viewer

7. Tormisheva, T., Tekhnologiya «vyrashchivaniya» malykh innovatsionnykh kompaniy malogo biznesa. Nekommercheskoe Partnerstvo "Instituty razvitiya malogo i srednego biznesa». Retrieved October 20, 2021, from http://www.myshared.ru/slide/160454/ 
8. Dodu, A. (2009). Conceptul incubatorului de afaceri ca forme de promovare a IMM-urilor. Meridian Ingineresc, (3), 75-77. Retrieved October 20, 2021, from http://repository.utm.md/handle/5014/1440

9. Veverica, A., Znaceni, A. sh.a. (2015). Ghidul autoritecilor publice locale: elaborarea proiectelor, 1-131, Retrieved October 20, 2021, from https://www.calm.md/public/files/ghiduri/elaborare_proiect_ROM.pdf mijlocii, 1-164.

10. Stratan, A., \& Doga-Mirzak, M. (2016). ASHM, INCE, Sistemul de financare a intreprinderilor mici shi

Стаття надійшла 8.11.2021

Стаття прийнята до друку 22.11.2021

Доступно в мережі Internet 30.12.2021

Цитування згідно ДСТУ 8302:2015

Doga-Mirzac M. Indicators for the evaluation and monitoring activity of the university incubator // Food Industry Economics. 2021. Vol.13, Issue 4. P.22-26. doi 10.15673/fie.v13i4.2190

Cite as APA style citation

Doga-Mirzac M. (2021). Indicators for the evaluation and monitoring activity of the university incubator. Food Industry Economics, 13(4), 22-26. doi 10.15673/fie.v13i4.2190 